\title{
RESPON PERTUMBUHAN DAN HASIL BAWANG MERAH (Allium ascalonicum) TERHADAP PEMBERIAN ZAT PENGATUR TUMBUH DAN PUPUK NPK PADA TANAH SPODOSOL \\ (The Growth and Yield Response of Onion (Allium ascalonicum) of Giving The Plant Growth Regulators (PGR) and NPK Fertilizer to the Spodosol)l
}

\author{
Saputra, W.L.A ${ }^{1)}$, Lautt, B.S. ${ }^{1)}$, Asie, E.R. ${ }^{1)}$, dan Nyahu ${ }^{1)}$, \\ ${ }^{1)}$ Program Studi Agroteknologi Fakultas Pertanian Universitas Palangka Raya \\ Jl. Yos Sudarso Palangka Raya 73112 Kalimantan Tengah Indonesia \\ e-mail: wisnulesa@gmail.com
}

Diterima : 25/9/2017 Disetujui : 29/10/2017

\begin{abstract}
The purpose of this study was to determine the growth and yield of onion that were given growth regulator (PGR) and NPK fertilizer on spodosol. This study used Randomized Block Design (RBD) of factorial pattern with two factors: (1) growth regulator $\left(0,3,6\right.$, and $\left.9 \mathrm{~mL} \cdot \mathrm{L}^{-1}\right)$, and (2) NPK fertilizer $\left(0,150,300\right.$, and $\left.450 \mathrm{~kg} \mathrm{ha}^{-1}\right)$. The results of this study showed tha giving of PGR increased the crop growth rate of plants aged 14-21 day after planting $\left(1.057 \mathrm{~g} . \mathrm{m}^{-2}\right.$ day $\left.{ }^{-1}\right)$ and 21-28 day after planting $\left(1.089 \mathrm{~g} . \mathrm{m}^{-2}\right.$ day $\left.^{-1}\right)$ with the best concentration of $6 \mathrm{~mL} . \mathrm{L}^{-1}$ water. The best NPK fertilizer dosage of $300 \mathrm{~kg} \cdot \mathrm{ha}^{-1}$ was able to increase plant height at 42 day after planting $(46,89 \mathrm{~cm})$, leaf area 21, 28 and 35 day after planting $\left(541,22 \mathrm{~cm}^{2}, 717,37 \mathrm{~cm}^{2}\right.$, and $\left.714,29 \mathrm{~cm}^{2}\right)$, weight of fresh stover $(75,50 \mathrm{~g})$, weight of dry stover $(66,19 \mathrm{~g})$ and tuber weight per plot $(4,520,25 \mathrm{~g})$.
\end{abstract}

Key words : onion, plant growth regulator (PGR), NPK, spodosol

\begin{abstract}
ABSTRAK
Tujuan penelitian untuk mengetahui pertumbuhan dan hasil tanaman bawang merah yang diberi zat pengatur tumbuh (ZPT) dan pupuk NPK pada tanah spodosol. Penelitian ini menggunakan menggunakan Rancangan Acak Kelompok (RAK) pola faktorial dengan dua faktor, yaitu : (1) zat pengatur tumbuh $\left(0,3,6\right.$, dan $9 \mathrm{~mL} \cdot \mathrm{L}^{-1}$ air), dan (2) pupuk NPK $\left(0,150,300\right.$, dan $\left.450 \mathrm{~kg} \cdot \mathrm{ha}^{-1}\right)$. Hasil penelitian menunjukkan bahwa pemberian ZPT meningkatkan laju pertumbuhan tanaman umur 14-21 hst $\left(1,057 \mathrm{~g} \cdot \mathrm{m}^{-2}\right.$. hari $\left.{ }^{-1}\right)$ dan 21-28 hst $\left(1,089 \mathrm{~g} \cdot \mathrm{m}^{-2}\right.$. hari $\left.{ }^{-1}\right)$ dengan konsentrasi terbaik 6 mL. $\mathrm{L}^{-1}$ air. Dosis pupuk NPK terbaik $300 \mathrm{~kg} \cdot \mathrm{ha}^{-1}$ mampu meningkatkan luas daun umur 21, 28 dan 35 hst, masing-masing $541,22 \mathrm{~cm}^{2}, 717,37 \mathrm{~cm}^{2}$, dan $714,29 \mathrm{~cm}^{2}$, bobot brangkasan segar $(75,50$ $\mathrm{g})$, bobot brangkasan kering $(66,19 \mathrm{~g})$ dan bobot umbi per petak $(4.520,25 \mathrm{~g})$.
\end{abstract}

kata kunci: bawang merah, zat pengatur tumbuh (ZPT), NPK, spodosol

\section{PENDAHULUAN}

Bawang merah merupakan komoditas sayuran yang memiliki banyak manfaat dan bernilai ekonomi tinggi. Produksi bawang merah Kalimantan Tengah tahun 2014 menurut statistik pertanian 2015 adalah sebesar 125 ton sedangkan produksi tahun
2013 sebesar 56 ton, terjadi kenaikan produksi sebesar 69 ton $(123,39 \%)$. Kenaikan ini disebabkan karena perluasan area panen sebesar 47 ha $(587,50 \%)$. Budidaya bawang merah yang ada hanya bisa memasok sekitar 10\% - 15\% dari kebutuhan masyarakat Kalimantan Tengah. Komoditi ini sangat fluktuatif harga maupun produksinya, hal ini 
terjadi karena pasokan produksi yang tidak seimbang antara hasil panen dan kebutuhan masyarakat pada setiap musimnya. Pada saat musim hujan, produksi bawang merah umumnya menurun, diikuti dengan harga yang tinggi. Beberapa hasil penelitian menunjukkan bahwa salah satu perbaikan teknologi budidaya untuk peningkatan produktivitas bawang merah ialah melalui penggunaan bibit unggul. Baswarsiati (2009) mengatakan varietas bauji tumbuh dan berproduksi lebih baik dimusim hujan karena varietas ini lebih menyukai pada kelembaban udara yang tinggi dan tahan terhadap curah hujan yang tinggi mulai awal pertumbuhan sampai tanaman panen. Produksinya berkisar antara 13,5 17,6 ton.ha ${ }^{-1}$ dan tahan terhadap Alternaria porii (Baswarsiati dan Nurbanah 2001 dalam Udiarto et al., 2015).

Salah satu upaya untuk meningkatkan produksi bawang merah dapat dilakukan dengan cara pemberian hormon tanaman atau zat pengatur tumbuh (ZPT). Penelitian ini menggunakan ZPT Hormax yang berperan dalam merangsang proses pertumbuhan dan pembesaran umbi. Sahroni et al. (2015), melaporkan pemberian ZPT Hormax mampu meningkatkan produksi berupa diameter subang pada tanaman gladiol (Gladiolus hybridus L.).

Selain pemberian ZPT, pertumbuhan dan hasil bawang merah dapat ditingkatkan dengan memberikan pupuk nitrogen $(\mathrm{N})$, fosfor $(\mathrm{P})$, dan kalium $(\mathrm{K})$ dalam jumlah yang cukup dan berimbang. Saputra (2016) melaporkan, aplikasi pupuk majemuk NPK (16:16:16) berpengaruh nyata terhadap pertumbuhan dan hasil tanaman bawang merah.

Kebutuhan hara bawang merah pada penanaman di tanah spodosol yang tergolong miskin hara, dapat terpenuhi dengan pemberian pupuk NPK dan dikombinasikan dengan pemberian ZPT hormax yang mengandung hormon lengkap dan ditambah dengan asam humik akan sangat mendukung pertumbuhan dan perkembangan tanaman sehingga hasil panen yang diperoleh akan meningkat.

Tujuan dari penelitian ini adalah untuk mengetahui respon pertumbuhan dan hasil bawang merah terhadap pemberian ZPT dan pupuk NPK pada tanah Spodosol.

\section{BAHAN DAN METODE}

Penelitian ini dilaksanakan pada bulan April sampai Juni 2017 di Kelurahan Banturung, Kecamatan Bukit Batu, Kota Palangka Raya.

Bahan-bahan yang digunakan adalah bibit bawang merah varietas Bauji, ZPT Hormax, pupuk majemuk NPK (16-16-16), SP-36, dolomit, pupuk kotoran ayam, pestisida, dan plastik transparan.

Penelitian ini menggunakan Rancangan Acak Kelompok (RAK) faktorial terdiri dari 2 faktor. Faktor pertama adalah ZPT $(0,3,6,9)$ mL. $\mathrm{L}^{-1}$ air dan faktor kedua adalah NPK $(0$, 150, 300, 450) kg.ha ${ }^{-1}$. Masing-masing kombinasi perlakuan diulang tiga kali sehingga terdapat 48 satuan percobaan.

Petakan yang digunakan berukuran 180 $\mathrm{cm} \times 135 \mathrm{~cm}$ dengan jarak tanam $20 \mathrm{~cm}$ x 15 $\mathrm{cm}$. Pemupukan dilakukan saat tanaman berumur 7, 15 dan 30 hst, dengan cara membuat larikan kemudian pupuk ditabur dan dibumbun. Sedangkan Pemberian ZPT dilakukan saat tanaman berumur 7, 17, 27, dan 37 hst dengan cara disemprot ke daun dan daerah perakaran secara merata. Volume semprot yang digunakan yaitu 500 L.ha ${ }^{-1}$ atau setara dengan $2 \mathrm{~mL} \cdot \tan ^{-1}$.

Variabel yang diamati adalah luas daun, laju pertumbuhan tanaman, jumlah umbi per rumpun, bobot brangkasan segar, bobot brangkasan kering, dan bobot umbi per petak.

Data hasil penelitian dianalisis menggunakan analisis ragam (uji F) pada taraf $\alpha 5 \%$. Apabila terdapat perbedaan nyata dari hasil analisis ragam, maka dilanjutkan dengan uji Jarak Berganda Duncan pada taraf $\alpha$ 5\%. 


\section{HASIL DAN PEMBAHASAN}

\section{Luas Daun}

Hasil analisis ragam menunjukkan bahwa interaksi antara pemberian ZPT dan pupuk majemuk NPK tidak berpengaruh nyata terhadap luas daun bawang merah pada semua umur pengamatan, pengaruh sangat nyata perlakuan pupuk majemuk NPK terjadi pada umur 21, 28 dan 35 hst dan tidak terjadi pengaruh nyata baik perlakuan tunggal maupun interaksi pada umur 14, 42 dan 49 hst.

Pemupukan yang sesuai dengan kebutuhan tanaman pada setiap fase pertumbuhannya, maka akan menunjang pertumbuhan vegetatif tanaman secara optimal sehingga menghasilkan daun yang lebih luas. Wibowo (1998) menyatakan pertumbuhan tanaman yang lebih baik dapat tercapai apabila unsur hara yang dibutuhkan untuk pertumbuhan dan perkembangan berada dalam bentuk tersedia, seimbang dan jumlah yang optimum.

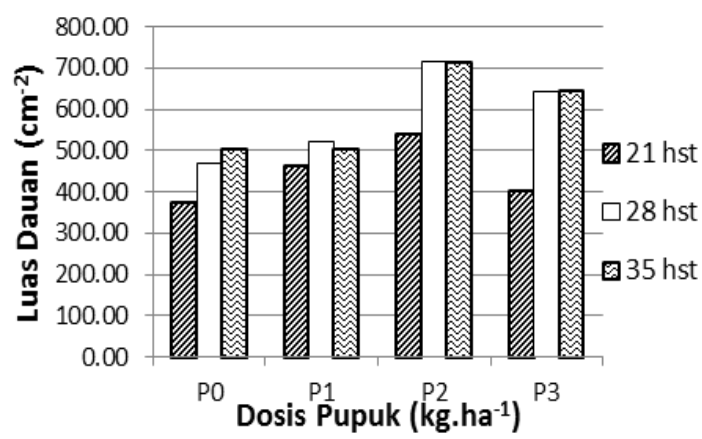

Gambar 1. Rata-rata luas daun $\left(\mathrm{cm}^{2}\right)$ bawang merah umur 21, 28, dan 35 hst. P0 (tanpa pupuk), P1 (NPK 150 kg.ha ${ }^{-1}$ ), P2 (NPK 3000 kg.ha $\left.{ }^{1}\right)$ dan P3 (NPK $\left.450 \mathrm{~kg}^{\circ} \mathrm{ha}^{-1}\right)$

Unsur hara nitrogen $(\mathrm{N})$ dibutuhkan tanaman pada fase vegetatif untuk pembentukan jaringan-jaringan tanaman khususnya batang, cabang dan daun. Unsur hara fosfor $(\mathrm{P})$ merupakan komponen penting penyusun senyawa untuk transfer energi (ATP dan nukleoprotein lainnya), untuk sistem informasi genetik (DNA dan RNA), untuk membran sel (fosfolipid) dan fosfoprotein, yang mempunyai fungsi penting dalam proses fotosintesis, dan unsur hara Kalium (K) mempunyai peran penting sebagai aktivator enzim dalam metabolisme tanaman. (Gardner et al., 1991; Singgih at al., 2000 dalam Sumarni et al., 2012)

Wardana et al., (2017) mengatakan ketersediaan hara yang cukup akan memberikan kontribusi peningkatan rata-rata nilai luas daun. Secara fisiologis semakin lama umur tanaman indeks luas daun tanaman akan semakin besar karena terjadi pertumbuhan. Cahaya yang di terima tanaman dengan luas daun besar akan lebih banyak dibandingkan dengan tanaman yang memiliki luas daun kecil.

\section{Laju Pertumbuhan Tanaman}

Hasil analisis ragam menunjukkan bahwa interaksi antara pemberian ZPT dan pupuk majemuk NPK tidak berpengaruh nyata terhadap laju pertumbuhan tanaman bawang merah pada semua umur pengamatan. Pengaruh nyata perlakuan pemberian ZPT terjadi pada umur 14-21 dan 21-28 hst dan tidak berpengaruh nyata baik perlakuan tunggal maupun interaksi pada umur 28-35, 35-42 dan 42-49 hst.

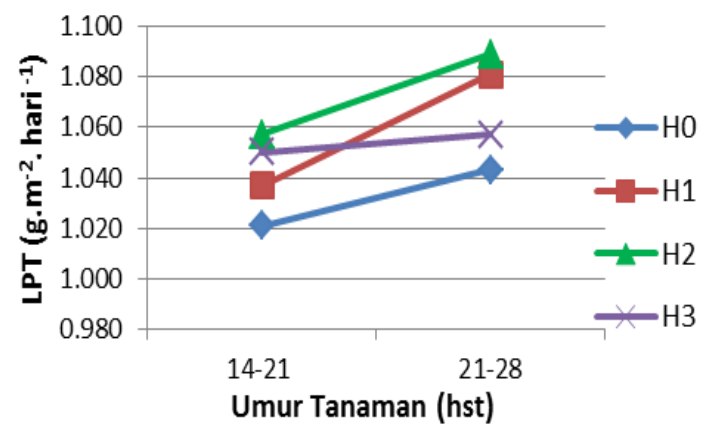

Gambar 2. Rata-rata laju pertumbuhan tanaman (g.m ${ }^{2}$.hari ${ }^{-1}$ ) bawang merah umur 21,28 , dan 35 hst. Keterangan H0 (tanpa ZPT), H1 (ZPT 3 ml. $1^{-1}$ ), H2 (ZPT 6 ml. $1^{-1}$ ) dan H3 (ZPT 9 ml.1 $\left.{ }^{1}\right)$.

Zat pengatur tumbuh (ZPT) sangat diperlukan untuk mendukung pertumbuhan dan perkembangan tanaman secara optimal. Pembentukan organ-organ tertentu sangat ditentukan oleh penggunaan yang tepat dari zat pengatur tumbuh yang ditambahkan. 
Sebab, sel-sel meristem selain aktif membelah secara alami juga mensintesis hormon endogen yang terdapat pada tanaman. Sehingga pada batas tertentu ZPT yang aplikasikan pada tanaman akan merangsang pertumbuhan tanaman sampai batas optimal mengingat hormon dibutuhkan tanaman dalam jumlah relatif kecil. Pemberian ZPT konsentrasi $6 \mathrm{~mL} \cdot \mathrm{L}^{-1}$ cukup untuk menunjang pertumbuhan tanaman bawang merah sehingga mampu menghasilkan laju pertumbuhan yang lebih baik.

Menurut Ramadan et al., (2016) penambahan hormon pengatur tumbuh pada batas konsentrasi optimum akan memicu pembelahan, pembesaran dan pemanjangan sel sehingga menunjang pertumbuhan tanaman karena hormon tumbuh merupakan salah satu komponen yang dibutuhkan dalam proses pertumbuhan tanaman selain karbohidrat dan nitrogen. Trisna et al., (2013) menambahkan adanya zat tumbuh yang ada dalam tubuh tanaman maupun hormon yang diberikan mampu memicu proses pertumbuhan. Zat pengatur tumbuh berfungsi mendorong pertumbuhan, dimana dengan pemberian zat pengatur tumbuh terhadap tanaman dapat merangsang penyerapan hara oleh tanaman secara maksimal sehingga laju pertumbuhan tanaman meningkat.

Laju pertumbuhan tanaman bawang merah di taksir melalui berat kering tanaman yang diukur setiap minggu. Gardner et al., (1991) pertumbuhan sebagai peningkatan bahan kering sebagai akibat pembelahan, pembesaran dan diferensisasi sel. Pemberian ZPT dengan konsentrasi yang tepat $\left(6 \mathrm{~mL} . \mathrm{L}^{-1}\right)$ akan meningkatkan pembentukan bahan kering secara optimal sesuai umur tanaman. Tanaman atau organ tanaman dengan hormon yang cukup untuk pembelahan sel dan aliran karbohidrat serta nutrisi lainnya akan menyebabkan morfogenesis secara terus menerus sehingga laju pertumbuhan tanaman meningkat (Gardner et al., 1991).

\section{Jumlah Umbi per Rumpun}

Peningkatan konsentrasi ZPT dan dosis pupuk NPK yang diberikan cenderung memberikan respon peningkatan rata-rata jumlah umbi per rumpun walaupun secara statistik tidak berbeda nyata.

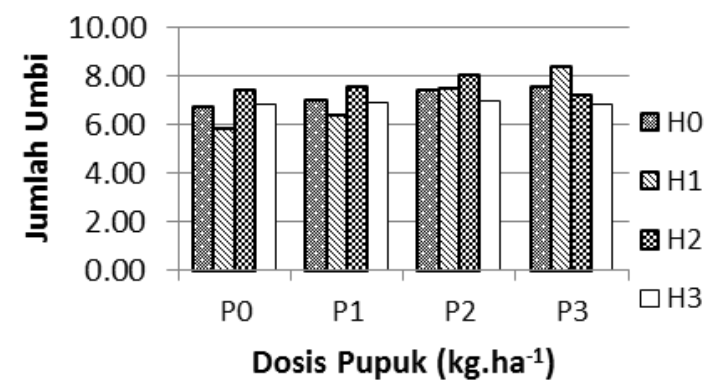

Gambar 3. Rata-rata jumlah umbi perumpun. H0 (tanpa ZPT), H1 (ZPT $3 \mathrm{ml}^{-1}{ }^{-1}$ ), H2 (ZPT 6 ml. ${ }^{-1}$ ), H3 (ZPT $9 \mathrm{ml}^{-1} \mathrm{l}^{-1}$, P0 (tanpa pupuk), P1

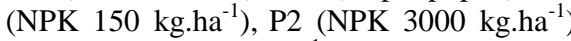
dan P3 (NPK 450 kg.ha- ${ }^{-1}$.

Pemberian ZPT dengan konsentrasi lebih tinggi $\left(9 \mathrm{~mL} \cdot \mathrm{L}^{-1}\right)$ mengakibatkan penurunan rata-rata jumlah umbi per rumpun. Hal ini diduga disebabkan oleh hormon yang diberikan berlebihan sehingga menghambat tanaman bawang merah membentuk anakan, mengingat hormon diperlukan tanaman dalam jumlah relatif kecil. Salisbury \& Ross (1995) mengatakan, pemberian auksin dalam jumlah besar akan memacu berbagai jenis sel tumbuhan untuk menghasilkan etilen. Goldsworthy dan Fisher (1996) menyatakan bahwa auksin pada kadar yang tinggi dapat menghambat pertumbuhan dan etilen yang berbentuk gas cenderung menghambat pertumbuhan. Diperjelas oleh Dimitry N Neljubow (1876-1926) dalam Salisbury \& Ross (1995), peningkatan etilen mempengaruhi pertumbuhan seperti terhambatnya pemanjangan batang tetapi penebalan batang bertambah, munculnya kebiasaan untuk tumbuh mendatar, perluasan helai daun terhambat, pelayuan dan akhirnya gugur daun serta terhambatnya pemanjangan akar dan meningkatnya kepekaan terhadap patogen. 
Sumarni et al, (2012) jumlah anakan bawang merah lebih banyak ditentukan oleh faktor genetik dari pada faktor pemupukan. Jumlah anakan sangat mempengaruhi jumlah umbi pada tanaman. Jika pembentukan anakan terhambat maka jumlah umbi bawang merah yang dihasilkan relatif sedikit. Hasil yang sama juga dilaporkan oleh Dirgantari et al, (2016), Fatmawaty et al, (2015) dan Syarfianda (2014) menyatakan bahwa pemberian pupuk organik atau pupuk $\mathrm{N}, \mathrm{P}$ dan $\mathrm{K}$ tidak berpengaruh nyata terhadap jumlah umbi tanaman bawang merah.

\section{Bobot Brangkasan Segar dan Bobot Brangkasan Kering}

Hasil analisis ragam menunjukkan bahwa interaksi antara pemberian ZPT dan pupuk majemuk NPK tidak berpengaruh nyata terhadap bobot brangkasan segar dan bobot brangkasan kering. Namun terjadi pengaruh nyata faktor tunggal pemberian pupuk majemuk NPK terhadap bobot brangkasan segar dan bobot brangkasan kering.

Pupuk majemuk NPK dapat meningkatkan hasil bawang merah baik bobot brangkasan segar maupun bobot brangkasan kering, namun terdapat kecenderungan bahwa pertambahan hasilnya semakin menurun dengan bertambahnya dosis pupuk NPK. Pemberian pupuk majemuk NPK $300 \mathrm{~kg} \cdot \mathrm{ha}^{-1}$ merupakan perlakuan terbaik karena menghasilkan bobot brangkasan tertinggi.

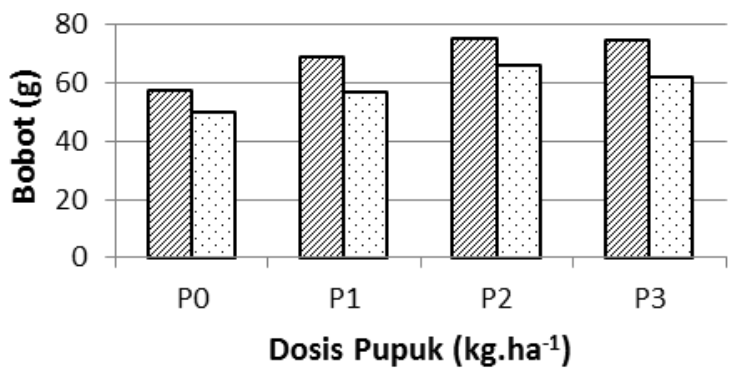

चbobot brangkasan segar $\square$ bobot brangkasan kering

Gambar 4. Rata-rata bobot brangkasan segar (g) dan bobot brangkasan kering (g). P0 (tanpa pupuk), P1 (NPK $150 \mathrm{~kg}^{-h^{-1}}$ ), P2 (NPK 300 kg.ha ${ }^{-1}$ ) dan P3 (NPK 450 kg.ha ${ }^{-1}$ ).
Hal ini diduga karena penyerapan hara yang lebih efektif dan pembentukan fotosintat yang lebih besar pada perlakuan yang diberi pupuk NPK $300 \quad \mathrm{~kg} \quad \mathrm{ha}^{-1}$ sehingga menghasilkan bobot brangkasan segar dan bobot brangkasan kering yang lebih baik dibandingkan dengan perlakuan lainnya. Enyi (1968) dan Karikari (1974) dalam Goldsworthy dan Fisher (1996) melaporkan, luas daun, hasil subang dan anakan umbi Xanthosoma meningkat dengan penambahan nitrogen dan kalium sampai tingkat pemupukan optimum dan kemudian variabel tersebut menurun pada pemberian pupuk dengan jumlah lebih tinggi.

Suntoro dan Astuti (2014), mengatakan pemberian pupuk NPK dapat meningkatkan ketersediaan unsur hara $\mathrm{N}, \mathrm{P}$ dan $\mathrm{K}$ yang dapat diserap oleh tanaman, sehingga dengan tersedianya unsur hara tersebut dapat memicu pertumbuhan dan perkembangan tanaman yang selanjutnya dapat memberikan hasil yang tinggi. Napitupulu dan Winarto (2010) melaporkan, pemberian $\mathrm{N}$ meningkatkan pertumbuhan dan produksi bawang merah dikarenakan $\mathrm{N}$ berperan dalam meningkatkan laju pertumbuhan tanaman. Menurut Goldsworthy dan Fisher (1996) Kalium meningkatkan laju fotosintesis dan translokasi fotosintat. Hal ini dikarenakan kalium mempengaruhi pembukaan dan penutupan stomata sehingga memperlancar proses fotosintesis. Ditambahkan Gardner et al, (1991) kalium mempunyai peran penting sebagai aktivator enzim dalam metabolisme tanaman dan meningkatkan translokasi hasil fotosintesis ke seluruh bagian tanaman sehingga pertumbuhan dan hasil tanaman optimal. Napitupulu dan Winarto (2010) melaporkan, penambahan kalium dengan dosis tinggi menunjukan hasil yang baik karena kalium berperan membantu proses fotosintesis, yaitu pembentukan senyawa organik baru yang diangkut ke organ tempat penimbunan, yaitu umbi. Pengaruh lain dari pemupukan kalium adalah menghasilkan umbi yang berkualitas. 


\section{Bobot Umbi per Petak}

Hasil analisis ragam menunjukkan bahwa interaksi antara pemberian ZPT dan pupuk majemuk NPK tidak berpengaruh nyata terhadap semua bobot umbi per petak. Namun terjadi pengaruh nyata faktor tunggal pemberian pupuk majemuk NPK terhadap bobot umbi per petak.

Nilai rata-rata luas daun yang lebih tinggi pada saat pertumbuhan dapat diindikasikan biomassa bagian tajuk yang lebih baik. Meningkatnya biomassa tajuk yang lebih baik akan sangat berpengaruh terhadap kemampuan tanaman untuk berfotosintesis lebih tinggi dan menghasilkan fotosintat yang lebih banyak. Hasil fotosintesis yang banyak dapat digunakan untuk pembentukan hasil panen yang tinggi. Sesuai dengan pernyataan Salisbury dan Ross (1992) bahwa, luas daun tanaman merupakan suatu faktor yang menentukan jumlah energi matahari yang dapat diserap oleh daun dan akan menentukan besarnya fotosintat yang dihasilkan. Fotosintat tersebut sangat menentukan hasil karena sebagian fotosintat ditimbun dalam organ reproduktif seperti umbi. Lakitan (1996) laju pertambahan berat umbi lebih ditentukan oleh fotosintat yang dihasilkan selama periode perkembangan umbi tersebut, sedangkan asimilat yang disintesis sebelum inisiasi umbi yang disimpan pada batang hanya memberikan kontribusi sekitar $10 \%$.

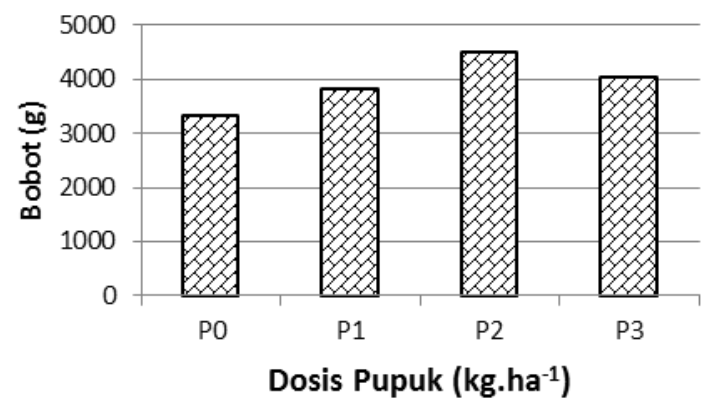

Gambar 5. Rata-rata bobot umbi (g) kering angin selama 7 hari. P0 (tanpa pupuk), P1 (NPK 150

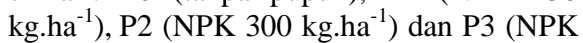
$\left.450 \mathrm{~kg} \cdot \mathrm{ha}^{-1}\right)$.

\section{KESIMPULAN DAN SARAN}

\section{Kesimpulan}

1) Tidak ada interaksi antara ZPT dan pupuk majemuk NPK terhadap pertumbuhan dan hasil tanaman bawang merah.

2) Pemberian ZPT berpengaruh terhadap laju pertumbuhan tanaman. Konsentrasi terbaik $6 \mathrm{~mL} . \mathrm{L}^{-1}$ menghasilkan laju pertumbuhan tanaman sebesar 1,057 g.m . $^{-2}$ hari ${ }^{-1}$ pada umur 14-21 hst dan 1,089 g.m $\mathrm{m}^{-2}$. hari ${ }^{-1}$ pada umur 21-28 hst.

3) Pemberian pupuk majemuk NPK dengan dosis $300 \mathrm{~kg} \cdot \mathrm{ha}^{-1}$ mampu memberikan pertumbuhan dan hasil terbaik (luas daun pada umur 21, 28 dan 35 hst masingmasing sebesar $541,22 \mathrm{~cm}^{2}, 717,37 \mathrm{~cm}^{2}$, $714,29 \mathrm{~cm}^{2}$; bobot brangkasan segar sebesar 75,50 g; bobot brangkasan kering sebesar 66,19 g dan bobot umbi per petak sebesar $4520,25 \mathrm{~g}_{\text {petak }}{ }^{-1}$ ).

\section{Saran}

1) Dari hasil penelitian disarankan untuk menggunakan pupuk majemuk NPK dengan dosis $300 \mathrm{~kg} \cdot \mathrm{ha}^{-1}$.

2) Perlu dilakukan penelitian lebih lanjut untuk mengetahui konsentrasi ZPT yang tepat untuk meningkatkan hasil panen bawang merah pada musim yang berbeda.

\section{DAFTAR PUSTAKA}

Barwasiati, 2009. Budidaya Bawang Merah dan Penanganan Permasalahnnya. (http://baswarsiati.wordpress.com/20 09/04/24).

Dirgantari, S., Halimursyadah \& Syamsuddin. 2016. Respon Pertumbuhan dan Hasil Bawang Merah (Allium ascalonicum) terhadap Kombinasi Dosis NPK dan Pupuk Kandang. Jurnal Ilmiah Mahasiswa Pertanian Unsyiah (1) $1 . \quad$ (www.jim. unsyiah.ac.id) (Diakses 12 Maret 2016). 
Fatmawaty, A. A., Ritawati, S \& Said, L. N. 2015. Pengaruh Pemotongan Umbi dan Pemberian Beberapa Dosis Pupuk NPK Majemuk terhadap Pertumbuhan dan Hasil Tanaman Bawang Merah (Allium ascalonicum L.). Agrogilia 4 (2) : 69-77. (Tersedia on-line dengan update di ejournal.unpatti.ac.id). (Diakses 7 Juli 2017)

Gardner, F. P., Pearce, R. B. \& Mitchell, R. L. 1991. Fisiologi Tanaman Budidaya. UI-Press. Jakarta.

Goldsworthy, P. R \& Fisher, N. M. 1996. Fisiologi Tanaman Budidaya Tropik. Terjemahan dari The Physiology of Tropical Field Crops. Gadjah Mada University Press . Yogyakarta.

Lakitan, B. 1996. Fisiologi Tumbuhan dan Perkembangan Tanaman. PT RajaGrafindo Persada. Jakarta.

Napitupulu, D dan Winarto, L. 2010. Pengaruh Pemberian Pupuk N dan K terhadap Pertumbuhan dan Produksi Bawang Merah. J.Hort. 20 (1) : 2735. (Tersedia on-line dengan update di

http://hortikultura.litbang.pertanian.g o.id/jurnal_pdf/201/napitupulubawan gmerah.pdf) (Diakses 13 Juli 2017).

Ramadan, V.R., Kendarini, N \& Ashari, S. 2016. Kajian Pemberian Zat Pengatur Tumbuh terhadap Pertumbuhan Stek Tanaman Buah Naga (Hylocereus costaricensis). Jurnal Produksi Tanaman. 4 (3) : 180-186. (Tersedia on-line dengan update https://media.neliti.com/media/publi cations/131356-ID-none.pdf) (Diakses 14 Juli 2017).

Sahroni, M.S. Andalasari, T.D., Nurmiat, Y. \& Widyastuti, R.A.D. 2015. Pengaruh Pemberian ZPT dan Komposisi Pupuk Tunggal (Urea, TSP, KCl) pada Pertumbuhan dan Produksi Tanaman Gladiol (Galdiolus hybridus L.). Seminar
Nasional Sains\&Teknologi VI Lembaga Penelitian dan Pengabdian Universitas Lampung (http://satek.unila.ac.id/wpcontent/uploads/2015/08/91Meda.pdf) . Diakses 10 Maret 2016. Salisbury, F.B. \& Ross, C. W. 1995. Fisiologi Tumbuhan. Jilid III. Terjemahan dari Plant Physiology. ITB. Bandung.Wibowo, S. 2009. Budidaya Bawang Merah, Bawang Putih, Bawang Bombay. Penebar Swadaya . Jakarta.

Saputra, P. A. 2016. Respon Tanaman Bawang Merah (Allium ascalonicum L.) Akibat Aplikasi Pupuk Hayati dan Pupuk Majemuk NPK dengan Berbagai Dosis. Skripsi. Fakultas Pertanian Universitas Lampung. Bandar Lampung. (Tersedia on-line dengan update di http:// digilib.unila.ac.id/ 23631/4/SKRIPSI\%20TANPA\%20 BAB\%20PEMBAHASAN.pdf) (Diakses 9 Desember 2016).

Statistik Pertanian. 2015. Statistik Pertanian (Agricutural Statistic) 2015. Pusat Data dan Sistem Informasi Pertanian Kementerian Pertanian. Jakarta.

Sumarni, N., Rosliana, R. \& Basuki, R. S. 2012. Respon Pertumbuhan, Hasil Umbi, dan Serapan Hara NPK Tanaman Bawang Merah terhadap Berbagai Dosis Pemupukan NPK pada Tanah Alluvial. J.Hort 22 (4) : 366-375. (Tersedia on-line dengan update di http://hortikultura.litbang. pertanian.go.id/jurnal_pdf/224/9-

Sumarni_Bawang.pdf) (Diakses 02 Maret 2016).

Suntoro \& Astuti, P. 2014. Pengaruh Waktu Pemberian dan Dosis Pupuk NPK Pelangi terhadap Pertumbuhan Tanaman Jagung Manis Varietas Sweet Boys (Zea mays saccharata Strut). Jurnal Agrifor 13 (2): 213222. (Tersedia on-line dengan update di 
https://media.neliti.com/media/publi cations/30110-ID-pengaruh-waktupemberian-dan-dosis-pupuk-npkpelangi-terhadap-pertumbuhantanama.pdf) (Diakses 28 Oktober 2017).

Syarfianda. 2014. Pengaruh Pemberian Kompos Kirinyuh dan Pupuk NPK terhadap Pertumbuhan dan Hasil Bawang Merah. Skripsi. Universitas Syiah Kuala. Aceh. (Tersedia on-line dengan update di http://etd.unsyiah.ac.id). (Diakses 07 Maret 2016).

Trisna, N., Umar, H \& Irmasari. 2013. Pengaruh Berbagai Jenis Zat Pengatur Tumbuh terhadap Pertumbuhan Stump Jati (Tectona grandis L. F). Warta Rimba 1 (1). (Tersedia on-line dengan update di http://download.portalgaruda.org/arti cle.php?article $=141855 \&$ val $=5156$ ) (Diakses 28 Oktober 2017).
Udiarto, B. K., Setiawati, W.\& Suryaningsih, E. 2015. Pengenalan Hama dan Penyakit pada Tanaman Bawang Merah dan Pengendaliannya. Balai Penelitian Tanaman Sayuran. Bandung. (http://balitsa.litbang.pertanian.go.id/ ind/images/isi monografi.pdf). Diakses 13 Desember 2016.

Wardana, I., Hasbi, H \& Wijaya I. 2017. Respon Pertumbuhan dan Produksi Tanaman Selada (Lactuca sativa L.) pada Pemberian Dosis Pupuk Kandang Kambing dan interval Waktu aplikasi Pupuk Cair Super Bionik. Agritop Jurnal Ilmu-Ilmu Pertanian. (Tersedia on-line dengan update di

Wibowo, S. 2009. Budidaya Bawang Merah, Bawang Putih, Bawang Bombay. Penebar Swadaya . Jakarta. 